\title{
A Brief Analysis on the Issue of Religious Belief of Contemporary College Students
}

\author{
Jing Chen \\ Henan University \\ Kaifeng, Henan, 475000
}

\begin{abstract}
Ideological and political work in colleges and universities is intended to make college students set up correct world outlook, the outlook on life, and the values, and become talents of Marxism ideological theory accomplishment. From the point of view of the current situation, there are some issues that ideological and political workers in colleges and universities must not ignore, for example, college students' being religious has become increasingly appeared in recent years. Therefore, we further analyze the cause and characteristic of this phenomenon, and makes suggestions on how to strengthen ideological and political work in colleges and universities.
\end{abstract}

Keywords-higher education; college students; mental health; religious belief

\section{INTRODUCTION}

College students' being religious is a social phenomenon, which has increasingly appeared in recent years. According to the survey of three thousand college students in nearly ten universities in Beijing at the turn of the century, college students professing all kinds of religion account for $9.2 \%$, which is far higher than the proportion of $1 \% \sim 3 \%$ that religious population of the former Soviet union teens aged 18 $\sim 30$ accounts for and is estimated by a sociologist of religion of the former Soviet union. The main object of this investigation is party members of college students and activists of application to join the party, and they both account for $60.16 \%$ of the surveyed. These two types of students in general is the relatively positive part of college students on politic and spirit, and its number is relatively less among college students, about $35 \%$ of college students. The emergence of this phenomenon reflects many social problems and diversified values' impact on teenagers during the period of social transformation, and also reflects the gap of ideological work in colleges and universities, which has brought new challenges for college ideological and political work.

\section{FACTORS IN THE FORMATION OF RELIGIOUS GROUPS OF COLLEGE STUDENTS}

According to the investigation and understanding, the formation of college students' being religious is based mainly on the following factors:

\section{A. Students' own factor, to seek comfort}

College students, as the leader of the Times, their thought is active, and at the same time, they have a very strong desire to acquire knowledge. College students' being religious also reflects Chinese religious general features that many people, in the event of a problem or producing requirements, start to profess religion. But it is different from ordinary people that the main reason of college students' being religious is due to the psychological adjustment requirement.

The influence of survival anxiety is namely the demand for religion. Once college students enter into university, they has stepped into a completely different life and learning environment from high school. Here, he has to deal with many problems about life and learning alone. His self-consciousness and reason consciousness is constantly awakening. He realizes many responsibilities and stress which he does not know or know not enough in high school. Faced with family survival, personal survival, individual conditions defects and other various pressure, when he cannot solve, cannot vent, cannot afford or lacks care from all aspects of society, religion will become the most effective heart refuge.

\section{B. Students in pursuit of the ultimate concern of life, namely the initiative religious}

Some religious college students are in excellent condition in various aspects, with rich and harmony families, and are intelligent, with excellent academic record, generally without problem of setbacks in life. But they have no experience of life, and with a naive idealism to look at society. However, it does not meet their social ideals, but has increasingly exposed many defects, so that they become cynical and apprehensive. When their education is too vague and rigid, and cannot explain all these very well, exquisite and profound religious doctrines with love and benevolence as the core are easy to avail the opportunity to get in.

\section{Students affected by family and national traditions}

The influence of family and traditional traditions is namely traditional religious. Religion has a long history in social history and the development of culture in China, has long-term impacted on people's spiritual and cultural life, and in the special period of historical development in our country and some areas, has formed the phenomenon that religion was in dominant position in political and ideological and cultural fields. According to the investigation and understanding, the reason why many college students profess religion is because someone in the family believe in religion, and they relatively trust family members, through close persons' influence, thus they go on the path of faithful believers, such a situation is 
relatively obvious in the coastal regions (Wenzhou, Taizhou, etc). Such students come to the school, and thus affect roommates, classmates, and friends around them, so fan out from point to area point, lead the surrounding people to the way of religion.

\section{The analysis on the current situation of ideological and political work in colleges and universities}

In recent years, the dominant education in school students work is more than the recessive education, and the rigid education more than the flexible education, ideal and belief.

Education is not specific, concrete or enough, especially the understanding for the relationship among the lofty ideal of human development, the national common ideal and the personal ideal is not enough, while education form is single and rigid, and the personalized humane care not enough. As a result, the contradiction between the ideal and the reality can easily make students lose ideal, confuse value view, or feel helpless or confused about what to do, so that they go towards the religion. The effect of ideological and political work in colleges and universities is not satisfactory. For the contents of the belief education in the colleges and universities, many college students feel boring and unattractive, don't feel attractive and persuasive, and consider that theory cannot connect with reality, and it is difficult to be accepted by students.

It is above all kinds of factors that contribute to the emergence of the religious groups of college students, in which except for the traditional believers, the rest all have this kind of association with their real life.

\section{THE ANALYSIS ON THE CHARACTERISTICS OF COLLEGE STUDENTS' BEING RELIGIOUS}

College students are part of the social groups of people with distinctive features. Though they come from different classes of society, they get together because of receiving higher education, and they communicate with each other, influence each other, complement each other. Coupled with educated youth being active, liking explore the unknown and other features, this makes religious groups of college students have remarkable characteristics which are different from other religious groups.

\section{A. Basically, the proportion of believers of male students and female students is flat.}

The survey shows that in college students' religious groups, male and female proportion is basically flat, and the emergence of this phenomenon can find the reason from the influence of Chinese traditional concept and the characteristics of college students' own situation.

\section{B. The demand of the psychological adjustment stands out.}

Chinese and foreign scholars agree that Chinese religious belief has a prominent feature of secular utilitarian consciousness. College students' being religious also reflects Chinese religious general features, usually many people, in the event of a problem or producing requirements, start to profess religion. But it is different from ordinary people that the main reason of college students' being religious is due to the psychological adjustment requirement.

College students are in a crucial stage of self-awareness gradually maturing, and are also in a critical period of personality formation. On the one hand, their sense of independence and sense of self-esteem are constantly growing. On the other hand, their psychological development has not yet matured, and self-regulation and self-control ability is not strong enough. Therefore, when dealing with the study, work, social, friendship, love, and complicated relationship between individual and collective, individual and country, intense psychological contradiction and conflict can often be caused, causing psychological disorder and imbalance in development, and bringing uncomfortable sense, depression and anxiety to psychological experience.

When college students have psychological barriers, it is necessary for students to seek release to regain the psychological balance. They will tell their parents, relatives and friends, teachers and other close persons for help, and some obtain guidance through psychological counseling department, and some go towards religion. The author had personally contacted with such a college student, when he could not free himself under pressure, first produced the idea of suicide, and then attempted to escape to Buddhist, hoping to find out prescription to get rid of psychological dilemma from the religion.

\section{THE ENLIGHTENMENT OF COLLEGE STUDENTS' BEING RELIGIOUS FOR IDEOLOGICAL AND POLITICAL WORK IN COLLEGES AND UNIVERSITIES}

Aimed at the current situation of college students' being religious, complicated causes and various vague understanding of religion, we should strengthen the guidance of positive education for college students to make them establish atheistical world outlook of materialism. In my point of view, we should focus on strengthening the education of the following three aspects:

\section{A. Attaching importance to the education of religious and cultural knowledge}

Attaching importance to the education of religious and cultural knowledge can help college students understand rich humanistic knowledge in human social cultural history, and its different manifestations, enrich college students' humanistic knowledge, increase their knowledge, and improve humanities quality. Strengthen exploration and research of religious culture and hot issues, and actively open lecture on hot issues, which are beneficial to correctly understand our country's religion's historical statues and role.

\section{B. Strengthening college students' ideal and belief education and other aspects education to enhance the effectiveness of the ideological and political work}

First of all, we should pay more attention to college students' mental health problems, and strengthen the ideal and belief education. Therefore, school should be the key to college students' ideal and belief education.

Secondly, we should strengthen college students' mental health education, which is conductive to cultivate comprehensive quality and ability, and is also people-oriented 
needs of the ideological and political education in colleges and universities. To conduct the targeted mental health education can help students practically solve existing confusion, difficulty and anxiety. College students' mental health education is helpful to achieve the goals of ideological and political education, which to some extent, can change the blind faith and blindly religious conformity, can make college students correctly understand the problems of history scientist religious, so as to make Marxism become play a leading role in college students' ideological understanding.

\section{Absorbing the beneficial ingredients from the religious propaganda}

The ideological and political work is designed to make people set up the correct world outlook, the outlook on life, and the values, and become striving upwards people with ideals and integrity. Religion is also concerned about world outlook, the outlook on life, and the values, emphasizing the soul purification, and compassion and universal love. Generally speaking, the ideological and political work has much greater influence than the influence of religion, but also can see in some places and some levels, the influence of religion is rapidly spreading. Especially among college students, the ideological and political work is confronted with considerable difficulties.

College students' religious belief is different from general religious beliefs, and its perceptual ingredient is much higher than the rational pursuit. Most of the so-called "religious" students lack understanding of religious beliefs in the true sense, and are not in strict accordance with the religious ceremony, standard and philosophy in social life and other aspects. Religion's adjustment role in such aspects as moral, interpersonal communication and life pursuit is not obvious. They do not have the outstanding characteristics of religious belief. We can say that most college religious students do have religious belief feature of religious believers in the full sense. But some students have a strong mental consciousness to seek religious asylum, and they mainly accept religious humanistic care, moral level and its expression form of art and beauty.

\section{REFERENCES}

[1] Jin Zhilin. Contemporary College Students and Religious Beliefs, Research on Contemporary Religion, 2002.

[2] Shen Deli, editor. Developmental and Educational Psychology, Shenyang: Liaoning University Press, 1999. 